\title{
Coexistence of Liver Hydatid Cyst and Brucellosis in an Adolescent
}

\author{
Adolesan Olguda Karaciğer Hidatik Kisti ve Bruselloz Birlikteliği
}

\section{Özge Metin Timur'1, Gönül Tanır', Çağatay Evrim Afşarlar², Gülsüm İclal Bayhan1', İsmet Faruk Özgüner²}

${ }^{1}$ Clinic of Pediatric Infectious Diseases, Dr. Sami Ulus Maternity and Children's Research and Education Hospital, Ankara, Turkey

${ }^{2}$ Clinic of Pediatric Surgery, Dr. Sami Ulus Maternity and Children's Research and Education Hospital, Ankara, Turkey

\begin{abstract}
A 15-year-old girl, who was evaluated for arthralgia of knees, was diagnosed as having brucellosis by serum agglutination and enzymelinked immunosorbent assay tests. Physical examination of the patient revealed massive hepatomegaly. Abdominal ultrasonography and computerised tomography showed a single large cystic lesion of the liver. The echinococcus indirect haemagglutination was positive at a titre of 1/1280. A giant hydatid cyst was removed with surgical intervention; in addition, she was treated with albendazole and antibrucellosis drug combination with success. Here, an immunocompetent adolescent case with brucellosis and concomitant hydatid cyst disease was reported to emphasise that the coexistence of both entities are infrequent but may occur due to increased prevalence of the diseases. (Turkiye Parazitol Derg 2013; 37: 147-50)
\end{abstract}

Key Words: Brucellosis, hydatid cyst, adolescent

Received: 01.02.2012

Accepted: 16.01 .2013

\section{ÖZET}

Dizlerde artralji nedeniyle araştıılan 15 yaşındaki kız hasta, serum aglutinasyon ve "enzyme linked immunosorbent" testler ile bruselloz tanısı aldı. Hastanın fizik muayenesinde massif hepatomegali saptandı. Abdominal ultrasonografi ve bilgisayarlı tomografide karaciğerde tek büyük kistik lezyon görüldü. Ekinokok indirekt hemaglutinasyon titresi 1/1280 titrede pozitifti. Cerrahi müdahele ile büyük hidatik kist çıkarıldı, ek olarak albendazol ve anti-bruselloz ilaç kombinasyonu ile başarı ile tedavi edildi. Burada bruselloz tanısı alan ve raslantısal olarak, karaciğer kist hidatiği saptanan, immün sistemi sağlam olan bir adolesan vaka, bu durumların birlikteliğinin sık olmadığı fakat bu hastalıkların artmış prevelansına bağlı olarak ortaya çıkabileceğini vurgulamak amacı ile sunuldu. (Turkiye Parazitol Derg 2013; 37: 147-50)

Anahtar Sözcükler: Bruselloz, hidatik kist, adolesan

Geliş Tarihi: 01.02.2012

Kabul Tarihi: 16.01.2013

\section{INTRODUCTION}

Zoonoses have been defined as diseases and infections that are naturally transmitted between vertebrate animals and humans. Organisms responsible for zoonoses are remarkably diverse and vary with respect to life cycles and modes of transmission. Zoonoses can cause illness in their natural hosts and are capable of infecting humans by direct contact with animals, animal bites, ingestion, inhalation, arthropod intermediates or combinations of the above (1).
Cyst hydatic disease caused by the tapeworm Echinococcus granulosus is a parasitic disease transmitted from the excrement of infected dogs. Echinococcus granulosus causes serious liver and lung cystic disease. Hydatid disease is one of the major community health problems, especially in Middle East and Mediterranean countries, including Turkey. The incidence of the disease in Turkey is $87-400 / 100,000$ (2).

Brucellosis is a zoonotic disease caused by Gram-negative bacteria, Brucella spp. Brucella infection spreads hae-

Address for Correspondence/ Yazışma Adresi: Dr. Özge Metin Timur, Clinic of Pediatric Infectious Diseases, Dr. Sami Ulus Maternity and Children's Research and Education Hospital, Ankara, Turkey Phone: +90 3123056544 E-mail: drozgemetintimur@gmail.com doi:10.5152/tpd.2013.32 
matogenously and mainly involves the reticuloendothelial system. Localised infections of other organs such as the joints, central nervous system, heart and kidneys may also occur. The disease spreads to humans via the ingestion of raw dairy products, the consumption of infected meat from domestic livestock and close contact with their secretions and carcasses. Brucellosis is the most prevalent zoonotic disease worldwide, and continues to be a major health problem in Turkey. According to the Turkish Ministry of Health records from 1970 to 2004, the number of cases of brucellosis increased from 37 to 18,408 (3).

Both of these zoonoses are among the widespread parasitic and bacterial diseases in Turkey. We discuss the coexistence of brucellosis and liver hydatic echinococcosis in an adolescent patient. We hypothesise that the coexistence of both entities is infrequent but may occur due to increased and uncontrolled incidence of the diseases.

\section{CASE REPORT}

A previously healthy 15 year-old girl was admitted to our hospital with the complaints of weight loss, weakness, a decrease in appetite for 4-months and knee pain of 3-week duration. She was living in the village of Gulsehir, Nevsehir; her family was dealing with animal husbandry and she frequently came into contact with sheep and dogs. It was learnt that her mother had been diagnosed with brucellosis two weeks ago and she also had a history of ingestion of unpasteurised milk and milk products.

On physical examination, the patient had arthralgia of knees but she appeared well and her vital signs were normal. There was massive hepatomegaly without splenic enlargement.

Results of laboratory tests were as follows: haemoglobin $8.8 \mathrm{~g} /$ dl, white blood count $4,700 / \mathrm{mm}^{3}$ with $50 \%$ polymorphonuclear leukocytes, 2\% eosinophils, 42\% lymphocytes, and 6\% monocytes, platelet count $250,000 / \mathrm{mm}^{3}$, C-reactive protein $6.85 \mathrm{mg} / \mathrm{L}$, erythrocyte sedimentation rate $65 \mathrm{~mm} / \mathrm{h}$. Renal and hepatic function tests were normal. Investigations showed a Brucella standard tube agglutination test (STA) titre of $1 / 400$, a coombs STA titre of $1 / 2560$, Brucella Ig M-lg $G$ was positive with enzyme immunoassay (EIA) and blood culture was negative for Brucella.

Abdominal ultrasonography (US) revealed a large cyst measuring $17 \times 16 \times 19 \mathrm{~cm}$ which included membranes and vesicles located in the right and caudate lobe of the liver. An abdominal computerised tomography scan revealed a single multivesiculer large cystic lesion $(21 \times 19 \times 16 \mathrm{~cm})$ resembling type 2 hydatid disease located in the right lobe of the liver which compresses the portal vein (Figure 1). The Echinococcus indirect haemagglutination test was positive at a titre of $1 / 1,280$. Thereafter, surgical treatment was planned to prevent the risk of large hydatid cyst rupture. Surgical exploration was performed under general anaesthesia via a right subcostal incision, and revealed a giant hydatid cyst arising from the right lobe of the liver which extended into the inguinal region and was covered with hepatic tissue. After the evacuation of cyst contents, closure of the biliary leakages into the cavity and omentoplasty were performed. The operation was successful.

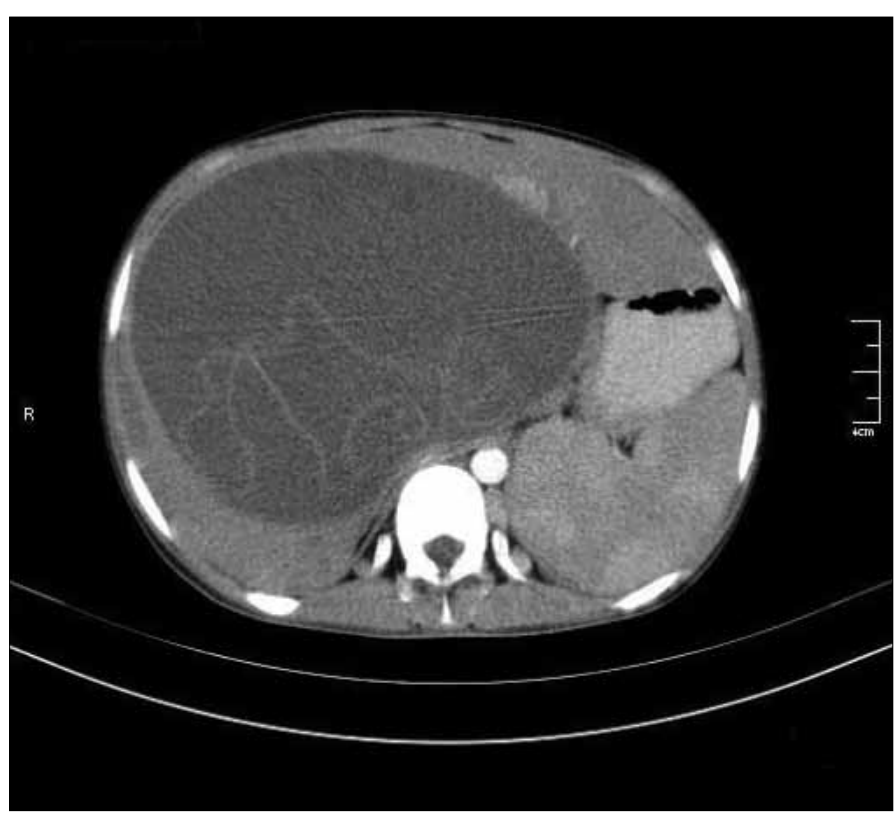

Figure 1. Axial computerised tomography image; a single multivesiculer large cystic lesion $(21 \times 19 \times 16 \mathrm{~cm})$ located in the right lobe of the liver which compresses to the portal vein

Anti-brucellosis treatment with the combination of doxycycline (200 mg/day, per orally) plus rifampicin (600 mg/day, per orally), and anti-echinococcal treatment with albendazole $(15 \mathrm{mg} / \mathrm{kg} /$ day, per orally) were commenced during the hospitalisation period of four weeks. Medical treatment of the patient was planned after discharge as six weeks for brucellosis and three rounds of 28 days with intervals of seven days for hydatid disease. At the end of the treatment regimens, she had no symptoms. The follow-up serum Brucella Ig M EIA tests and coombs STA titres were negative.

\section{DISCUSSION}

Cystic echinococcosis and brucellosis are zoonotic diseases that may lead to serious morbidity in humans; they continue to be a major health problem in Turkey. The distribution of these diseases is influenced by agricultural, economic and educational levels, cultural and hygienic habits.

Hydatid cyst is a parasitic disease caused by the tapeworm $E$. granulosus that is found in the small intestine of carnivores (e.g., dog), which are called the definitive host. The passed eggs of tapeworm, which are ingested by a herbivore (e.g., sheep), are called the intermediate host. The eggs hatch in the intestine of the herbivore, penetrate the intestinal wall, and reach the liver using the portal vein, where they develop into a hydatid cyst. Humans are accidental hosts and acquire the infection when they ingest tapeworm eggs by consuming contaminated vegetables or in contact with infected animals or contaminated soil. The ingested ova hatch in the human small intestine and penetrate through the portal circulation to the liver, lungs and other organs (4). Hydatid disease most commonly affects the liver and lungs; these two organs account for $90 \%$ of cases, but any organ may be affected. The spleen, skin, muscle, kidney, retroperitoneum, bone, heart, and brain were reported as other sites of involvement, in descending order of 
frequency (5). Cystic echinococcosis remains an important health problem in many regions of the world, both where no control measures have been implemented, and where control programs have been incompletely successful with ensuing reemergence of the disease (6). Although the infection may be acquired in childhood, most cases become symptomatic and are diagnosed in adulthood period because of its slowly growing nature. Cystic echinococcosis may be found incidentally on an US scan or chest $X$-rays requested for unrelated reasons. Of cyst hydatic patients, only $10-20 \%$ of cases are diagnosed below the age of 16 years (7). Our patient is also an adolescent patient. Large hydatid cysts of the liver are prone to rupture, even with minor blunt abdominal trauma, and compression to the adjacent abdominal organs is common. In accordance with World Health Organisation recommendations, the commonly accepted approach for hydatid cysts $>5 \mathrm{~cm}$ is surgical treatment; thus, the urgent surgical exploration for the giant hydatid cysts is essential (8). Surgical treatment of the hydatid cyst should include meticulous evacuation of the cyst contents without any spillage, closure of the minor biliary channels opening to the cavity, and preservation of the liver parenchyma (9). The evacuation of the cyst and omentoplasty for the residual cavity should be the treatment of choice for the surgical treatment of large hydatid cysts because of the successful results and lower abdominal complication rates $(10,11)$. Additionally, preoperative and postoperative albendazole treatments reduce the relapse rates (12). In our patient, after a successful operation, albendazole treatment was given. For the prevention of hydatid disease, sheep and cows should be slaughtered under the supervision of a veterinarian and unhealthy internal organs should be disposed of to avoid ingestion by dogs. The education of people is necessary for these issues. Stray dogs should be kept under control for the purpose of anti-helminthic drug administration.

In our country, the most common transmission route of brucellosis is the consumption of infected animal products, mainly raw cheese, like our patient (3). Moreover, her family were livestock keepers and had additional risk of occupational exposure of Brucella spp. whilst assisting in parturition or abortion of ruminants. Thus, the mother of the patient had been diagnosed as brucellosis. The signs and symptoms of brucellosis are not specific; the clinical diagnosis should always be confirmed by bacteriological or serological tests (13). It has been reported that the treatment of childhood brucellosis with co-trimoxazole + rifampicin ( $\leq 8$ years) or doxycycline + rifampicin ( $>8$ years) treatments are effective and have low relapse rates in Turkey (14). The diagnosis of brucellosis was made with compatible epidemiological, clinical findings and positive agglutination titre in our patient. The joint symptoms rapidly responded to the treatment. Early diagnosis and appropriate treatment improve the outcome. The avoidance of regular consumption of undercooked dairy products in households and control of the disease in animals with multidisciplinary efforts are preventive measures for these zoonotic diseases.

Although the present case was diagnosed as brucellosis, since she had incompatible findings of massive hepatomegaly for Brucella infection, cystic sonographic appearance was deter- mined and its results were incompatible for Brucella infection. Thereafter, hydatid disease of the patient had been diagnosed incidentally. In childhood brucellosis series, hepatomegaly was reported in 16\% to 69\%; an increase in transaminase values and mild hepatosplenomegaly were the most common $(14,15)$.

\section{CONCLUSION}

Certain human activities like the widespread rural practice of feeding dogs with the viscera of home-butchered sheep, the consumption of undercooked dairy products and the aspect of stray dogs are a significant part of daily life in Turkey; therefore, the control of both brucellosis and echinococcosis implies multidisciplinary intense efforts, such as financial resources and educational programs. Both of these zoonoses are widespread and have significant morbidity. The present case demonstrated that the presence of two irrelevant zoonotic infections may be concurrent. For this reason, the children who have epidemiological findings and clinical findings suggesting zoonosis should be evaluated with appropriate laboratory tests and imaging techniques meticulously. We conclude that investigations might be expanded, especially in the presence of unexpected findings regarding one zoonotic disease.

\section{Conflict of Interest}

No conflict of interest was declared by the authors.

Peer-review: Externally peer-reviewed.

\section{Author Contributions}

Concept - Ö.M.T., G.T.; Design - Ö.M.T., G.T.; Supervision Ç.E.A.; Literature Review -Ç.E.A, G.I., B.T., I.F.Ö.; Writing Ö.M.T., G.T., Ç.A.; Critical Review - G.T., I.F.Ö.

\section{Çıkar Çatışması}

Yazarlar herhangi bir çıkar çatışması bildirmemişlerdir.

Hakem değerlendirmesi: Dış bağımsız.

\section{Yazar Katkıları}

Fikir - Ö.M.T., G.T.; Tasarım - Ö.M.T., G.T.; Denetleme - Ç.E.A.; Literatür taraması - Ç.E.A., G.I., B.T., I.F.Ö.; Yazıyı yazan - Ö.M.T., G.T., Ç.A.; Eleştirel İnceleme - G.T., I.F.Ö.

\section{REFERENCES}

1. Kotton CN, Weinberg AN. Zoonoses. Mandell GL, Bennett JE, Dolin R, editors. Principles and Practice of Infectious Diseases. Philadelphia: 2010.p.3999-4007.

2. Kucuk C, Yilmaz N, Akyildiz H, Sozuer E. Surgical Treatment in Liver Cyst Hydatic Cases: Analysis of 276 Patients. Erciyes Medical Journal 2008; 30: 170-4.

3. Buzgan T, Karahocagil MK, Irmak H, Baran Al, Karsen H, Evirgen O, et al. Clinical manifestations and complications in 1028 cases of brucellosis: a retrospective evaluation and review of the literature. Int J Infect Di. 2010; 14: 469-78. [CrossRef]

4. Dziri C. Hydatid disease--continuing serious public health problem: introduction. World J Surg 2001; 25: 1-3. [CrossRef]

5. Acar A, Rodop O, Yenilmez E, Baylan O, Oncül O. Case report: primary localization of a hydatid cyst in the adductor brevis muscle. Turkiye Parazitol Derg 2009; 33: 174-6. 
6. Rojo-Vazquez FA, Pardo-Lledias J, Francos-Von Hunefeld M, Cordero-Sanchez M, Alamo-Sanz R, Hernandez-Gonzalez A, et al. Cystic echinococcosis in Spain: current situation and relevance for other endemic areas in Europe. PLoS Negl Trop Dis 2011; 5: e893. [CrossRef]

7. Moro P, Schantz PM. Echinococcosis: a review. Int J Infect Dis 2009; 13: 125-33. [CrossRef]

8. Eckert J, Gemmell MA, Meslin FX, Pawlowski ZS, eds. Echinococcosis in Humans: Clinical aspects, diagnosis and treatment. Paris, France: OIE/WHO publications, 2001.p.20-66.

9. Büyükünal $C$ : Hydatid disease, in Howard ER, Stringer MD, Colombani PM (eds): Surgery of the Liver, Bile Ducts and Pancreas in Children. London, UK, Arnold, 2002.p.355-62.

10. Aktan AO, Yalin R, Yeğen C, Okboy N. Surgical treatment of hepatic hydatid cysts. Acta Chir Belg 1993; 93: 151-3.

11. Dziri C, Paquet JC, Hay JM, Fingerhut A, Msika S, Zeitoun G, et al. Omentoplasty in the prevention of deep abdominal complications after surgery for hydatid disease of the liver: a multicenter, prospective, randomized trial. French Associations for Surgical Research. J Am Coll Surg 1999; 188: 281-9. [CrossRef]

12. Manterola C, Mansilla JA, Fonseca F. Preoperative albendazole and scolices viability in patients with hepatic echinococcosis. World J Surg 2005; 29: 750-3. [CrossRef]

13. Clavijo E, Díaz R, Anguita A, García A, Pinedo A, Smits HL. Comparison of a dipstick assay for detection of Brucella-specific immunoglobulin $\mathrm{M}$ antibodies with other tests for serodiagnosis of human brucellosis. Clin Diagn Lab Immunol 2003; 10: 612-5.

14. Tanir G, Tufekci SB, Tuygun N. Presentation, complications, and treatment outcome of brucellosis in Turkish children. Pediatr Int 2009; 51: 114-9. [CrossRef]

15. Giannakopoulos I, Nikolakopoulou NM, Eliopoulou M, Ellina A, Kolonitsiou F, Papanastasiou DA. Presentation of childhood brucellosis in Western Greece. Jpn J Infect Dis. 2006; 59: 160-3. 